\title{
Supervised Learning-Aided Control of a DC-DC Power Converter in Wind Energy Conversion Systems
}

\author{
Rüzgâr Enerjisi Dönüşüm Sistemlerinde bir DC-DC Güç Dönüştürücüsünün Denetimli \\ Ögrenme Destekli Kontrolü \\ Alper Nabi AKPOLAT ${ }^{1}{ }^{(D)}$, Erkan DURSUN ${ }^{1}{ }^{(D)}$, Ahmet Emin KUZUCUOĞLU ${ }^{1}$ (D) \\ ${ }^{1}$ Marmara University, Department of Electrical-Electronics Engineering, 34854, Istanbul, Turkey
}

\begin{abstract}
Over the last decades, to adopt high penetration of renewable energy sources (RESs) in electrical energy systems, distributed energy resources (DERs) have become prominent. Due to easy attainability status of small wind turbines (WTs), wind energy conversion systems (WECSs) are feasible applications for small customers, especially in windy areas. The next decade is likely to witness a considerable rise in DERs. In this context, WECSs are preferred broadly, thus harvesting wind energy into electrical energy effectively is a substantial issue. WTs can be got involved in the grid-connected or autonomous mode with a variety of topologies. In this paper, we examine to control of DC-DC boost converter of a WECS with the help of artificial intelligence (AI)-aided PI controller based on supervised learning method. Regarding the proposed method, artificial neural networks (ANNs) as a subset of AI are utilized. To test and ensure the applicability of the proposed control method, a small WECS with a permanent magnet synchronous generator (PMSG) connected a DC bus was implemented in MATLAB/Simulink environment. The proposed ANN scheme has reached a high accuracy rate with an overall mean squared error (MSE) equal to 7.4e-08. The results present that dynamic response and less complexity with a high accuracy rate have been obtained under study. The main target of this study is to reduce the number of sensors in the control layer. Thus, a costeffective and more reliable structure is obtained with fewer sensor requirements.
\end{abstract}

Keywords: Wind Energy Conversion Systems, Artificial Intelligence, Artificial Neural Networks, DC-DC Power Converters

Öz

Son on yıllarda, elektrik enerjisi sistemlerinde yenilenebilir enerji kaynaklarının yüksek oranda nüfuzunu yaygınlaştırmak için dağıtılmış enerji kaynakları öne çıkmıştır. Küçük rüzgâr türbinlerinin kolay erişilebilirlik durumu nedeniyle, rüzgâr enerjisi dönüşüm sistemleri özellikle rüzgârlı alanlarda küçük müşteriler için elverişli uygulamalardır. Önümüzdeki on yıl muhtemelen dağıtık enerji kaynakları önemli bir artışa tanık olacaktır. Bu bağlamda, rüzgâr enerji dönüşüm sistemleri yaygın olarak tercih edilmektedir, bu nedenle rüzgâr enerjisinin elektrik enerjisine etkin bir şekilde dönüştürülmesi önemli bir konudur. Rüzgâr türbinleri çeşitli topolojilerle şebekeye bağlı veya otonom modda dâhil edilebilirler. Bu makalede, denetimli öğrenme yöntemine dayalı yapay zekâ destekli PI denetleyicisi yardımıyla bir rüzgâr enerji dönüşüm sistemindeki yükselten DC-DC güç dönüştürücüsünün kontrolünü incelemekteyiz. Önerilen yöntemle ilgili olarak, yapay zekânın bir alt kümesi olarak yapay sinir ağları kullanılmaktadır. Önerilen kontrol yönteminin uygulanabilirliğini test etmek ve doğrulamak için, MATLAB/Simulink ortamında bir DC baraya sabit mıknatıslı senkron generatör ile küçük bir rüzgar enerji dönüşüm sistem uygulanmıştır. Önerilen YSA şeması, 7.4e-08'e eşit toplam ortalama karesel hata (MSE) ile yüksek bir doğruluk oranına ulaşmıştır. Sonuçlar, çalışma kapsamında dinamik yanıtın ve daha az karmaşıklığın yüksek doğruluk ile elde edildiğini göstermektedir. Bu çalışmanın ana hedefi, kontrol katmanındaki sensör sayısını azaltmaktır. Böylece daha az sensör gereksinimi ile uygun maliyetli ve daha güvenilir bir yapı elde edilmektedir.

Anahtar Kelimeler: Rüzgâr Enerjisi Dönüşüm Sistemleri, Yapay Zekâ, Yapay Sinir Ağları, DC-DC Güç Dönüştürücüleri

\section{INTRODUCTION}

\subsection{Motivation and Background}

The availability of energy is not the only concern for today's power systems. Another critical factor is its impact on consuming resource deficiency. Energy demand figures are expected to increase further due to the growing population, modernization, and globalization. Human beings have produced energy in conventional ways and still resume for years. However, it is inevitable that energy production is gradually abandoned the conventional ways due to both the depletion of resources and environmental concerns. This mandatory transition leads humanity to energy production with renewable energy sources (RESs). For RES-based applications, power electronics have grown into an accepted choice to supply sustainable power, since their complexity and performance have been boosted. Furthermore, several barriers that affect the efficiency of power electronics exist. Accomplishing these barriers demands to handle complicated optimization difficulties, which are challenging to alleviate through conventional methods [1]. 
One of the most preferred RES-based systems, i.e., distributed energy resources (DERs) is that wind energy conversion systems (WECSs) are operated with the help of power electronic converters according to system topology. The WECSs are largely popular structures, which are preferred to feed electrical appliances in any circumstance [2]. Thereby, a safe and reliable power supply is directly related to the robust control and management of power electronics. In other words, power electronics can be considered as an easy linker of DER applications. However, the coordination of these power electronics interfaces causes many problems in the control layer due to the intermittent nature of RESs and their uncertainty.

The desired characteristics of the control system should comprise tracking the output reference values (e.g., current and voltage), ensuring the presence and reliability of the power balance. Unlike classical control methods, this paper proposes the exploitation of a supervised learning-based multi-layer feedforward artificial neural network (ANN) to accomplish efficiency with high accuracy and to reduce the number of sensors in the control layer. We can implement the model of machine learning in various ways, ANNs are one of them. Thereby, the ANNs are a subset of machine learning and artificial intelligence (AI) targets to facilitate systems with intelligence that is susceptible to human-like learning and reasoning.

Nowadays, AI has palpable advantages by having been successfully applied in innumerable areas such as recognition, classification, computer vision, energy, and vehicle technology, etc [3]. To this end, the proper control of power electronics has crucial for dealing with control difficulties, which should be taken into consideration.

\subsection{Related Literature}

Upon relevant literature, it is obvious that many researchers have addressed the application of AI methods such as ANN, fuzzy, deep learning, or hybrid methods etc. in power electronics [4]-[6]. In particular, similar topology and controller have been studied as being an experimental setup with a wind turbine (WT) emulator recently [7]. Few researchers have mentioned estimating accurate wind speed to harvest maximum power with sensorless control using AI algorithms in [8]. Similarly, maximizing effective power is discussed profitably with the aid of ANN-based reinforcement learning for a WECS via permanent magnet synchronous generator (PMSG) [9]. The authors in [10], suggest that sliding mode observer outperforms in tracking error than ANN-based observer as a sensorless control of PMSG in WECS; however, sliding mode observer deteriorates with chattering issue. To control the back-to-back power converter of a WECS, space vector-based pulse width modulation (SVPWM) has been developed through a feedforward ANN by obtaining lower total harmonic distortion
(THD) [11]. On the other hand, an ANN-based voltage estimation for the calculation of THD is presented for multi-bus islanded AC microgrids [12]. Especially, a seamless estimated current data is implemented to support the control operation of a small WECS with the help of supervised learning-based ANN [13]. In [14], another RES-based system is that a PV panel is monitored for perceiving in case of the PV panel encounter degradation due to any faults. In other respect, to facilitate the operation of the energy management as reliable an ANN-based sensorless control [15] is proposed to eliminate the implemented sensors.

Various approaches have been put forward to come around the barriers against efficiency and performance. Except for estimating current data, in [16] it is seen that wind speed and torque data are observed properly with sensorless control for small WT clusters throughout a direct torque control algorithm. Much work on the potential of the sensorless control has been carried out [17], yet there are still some critical issues about maximum power point tracking (MPPT) algorithm is applied to harvest maximum power from the wind [18]. As can be clearly seen in Table 1, the most recent studies with similar applications are given based on the related literature.

Table 1. Comparison between related studies.

\begin{tabular}{|c|c|c|c|}
\hline $\begin{array}{l}\text { SCHEME } \\
\text { REF. }\end{array}$ & APPLICATION & SCHEME REF. & APPLICATION \\
\hline $\begin{array}{l}\text { ANN-Based } \\
\text { MPC [19] }\end{array}$ & $\begin{array}{l}\text { Control of } \\
\text { power } \\
\text { converters }\end{array}$ & $\begin{array}{l}\text { Artificial neural } \\
\text { network [23] }\end{array}$ & $\begin{array}{l}\text { Intelligent long- } \\
\text { term } \\
\text { performance } \\
\text { analysis }\end{array}$ \\
\hline $\begin{array}{l}\text { FCS-MPC- } \\
\text { based NN } \\
\text { Classifier } \\
{[20]}\end{array}$ & $\begin{array}{l}\text { Voltage sag } \\
\text { classification in } \\
\text { PV system }\end{array}$ & $\begin{array}{l}\text { Artificial } \\
\text { Neural } \\
\text { Networks [24] }\end{array}$ & $\begin{array}{l}\text { Cyberattack } \\
\text { detection \& } \\
\text { mitigation for } \\
\text { microgrids }\end{array}$ \\
\hline $\begin{array}{l}\text { Long short- } \\
\text { term memory } \\
\text { NN (LSTM) } \\
{[21]}\end{array}$ & $\begin{array}{l}\text { Power } \\
\text { prediction for } \\
\text { virtual plants }\end{array}$ & $\begin{array}{l}\text { MPC Using } \\
\text { ANN [25] }\end{array}$ & $\begin{array}{l}\text { Control of DC- } \\
\text { DC Converters }\end{array}$ \\
\hline $\begin{array}{l}\text { Proposed } \\
\text { ANN-Based } \\
\text { PI [13] }\end{array}$ & $\begin{array}{l}\text { Sensorless } \\
\text { control of DC- } \\
\text { DC converter }\end{array}$ & $\begin{array}{l}\text { Batch } \\
\text { normalization } \\
\text { neural network } \\
(\mathrm{BN}-\mathrm{NN}) \text { [26] }\end{array}$ & $\begin{array}{l}\text { Circuit } \\
\text { parameter } \\
\text { design of the } \\
\text { converter }\end{array}$ \\
\hline $\begin{array}{l}\text { Multilayer } \\
\text { Perception } \\
\text { ANN [22] }\end{array}$ & $\begin{array}{l}\text { Intelligent } \\
\text { energy } \\
\text { management }\end{array}$ & $\begin{array}{l}\text { Lagrange } \\
\text { programming } \\
\text { neural network } \\
\text { (LPNN) [27] }\end{array}$ & $\begin{array}{l}\text { Obtaining } \\
\text { optimal } \\
\text { scheduling for } \\
\text { microgrid }\end{array}$ \\
\hline
\end{tabular}

\subsection{Contributions and Organization}

Estimating current data enables power estimation as well. We do not only assert controlling a power converter of the WECS via ANN but also provide more reliable operation with less measured data in the control layer. This paper proposes to control a DC-DC boost converter with the aid of ANNs. The strong 
aspects of this paper can be divided into three matters: 1) the applied ANN possesses high accuracy to estimate the desired output, which is easy to apply, thanks to the proper input selection, 2) after an offline (training) phase of the application, the results validate that the online (exploitation) phase is conducted effectively, 3) this proposed AI-aided control via ANN increase the reliability of the system by reducing the used sensor in the control layer, as the measured sensor may corrupt, 4) the proposed method decreases the cost of ownership of sensors in the control layer and lastly 5) the estimated sensor's data communication challenge is removed.

The reminder of this paper is organized as follows. Section II explains about the WECS under study. Section III elucidates system control strategy for online and offline operation. Section IV evaluates the simulation results of the paper. Finally, conclusion remarks are stated in Section V.

\section{WIND ENERGY CONVERSION SYSTEM UNDER STUDY}

The mentioned WECS model can be split up into four parts regarding WT, PMSG, three-phase full-bridge diode rectifier, and lastly DC-DC boost converter.

Variable wind speed profile is used for power extraction from the wind. The WT has a vertical axis turbine of three blades with fixed pitch angle $(\beta)$ is equal to $0^{\circ}$. The WT has coupled with a three phase PMSG to generate power and then dispatch that power to the DC-DC converter with a full bridge diode rectifier. The synchronous generators are broadly preferred for variable wind speed in WT applications due to their low rotation synchronous speeds which track grid frequency. Therefore, it is worth using PMSG in these applications where the wind speed has too much fluctuation [28].

The configuration of the WECS can be illustrated in Figure 1. The maximum value of phase voltage is $V_{m}$, average output of the rectifier voltage $V_{o}$ is $V_{D C}$ and it is expressed as

$V_{D C}=\frac{1}{T} \int_{0}^{T} V_{0}(t) d t$

Using equation (3), the average voltage of the output $V_{D C \text {-out }}$ can be found as

$$
V_{D C-\text { out }}=\frac{6}{2 \pi} \int_{\pi / 3}^{2 \pi / 3} \sqrt{3} V_{m} \sin \theta d \theta
$$

or

$$
V_{D C-o u t}=V_{m} \frac{3 \sqrt{3}}{\pi}=1.654 V_{m}
$$

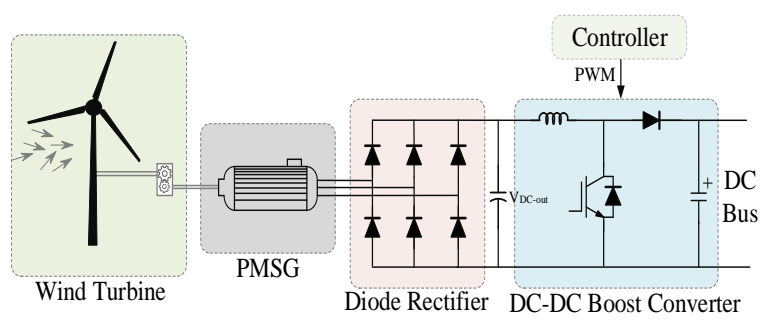

Figure 1. Configuration of WECS under study.

The WT power characteristics versus turbine speed can be expressed in Figure 2. The turbine output power can be seen that it coincides $320 \mathrm{~W}$ for 0.8 per unit of nominal mechanical power at base wind speed, so the nominal output power corresponds to $400 \mathrm{~W}$. The output power and mechanical torque of the WECS can be aligned by following equations. The output power of the turbine is defined as

$$
P_{m}=c_{p}(\lambda, \beta) \frac{\rho A}{2} v_{\text {wind }}^{3}
$$

where, $P_{m}$ is Mechanical output power of the turbine (W), $c_{p}$ is the performance coefficient of the turbine, $\rho$ is air density $\left(\mathrm{kg} / \mathrm{m}^{3}\right), A$ is the turbine swept area $\left(\mathrm{m}^{2}\right)$, $V_{\text {wind }}$ the wind speed $(\mathrm{m} / \mathrm{s}), \lambda$ is tip speed ratio of the rotor blade tip speed to wind speed, and lastly $\beta$ the blade pitch angle (degree). An equation is used to model $c_{p}(\lambda, \beta)$ that based on the modeling turbine characteristics [29] as follows:

$c_{p}(\lambda, \beta)=c_{1}\left(c_{2} / \lambda_{i}-c_{3} \beta-c_{4}\right) e^{-c_{5} / \lambda_{i}}+c_{6} \lambda$

with

$\frac{1}{\lambda}=\frac{1}{\lambda+0.08 \beta}-\frac{0.035}{\beta^{3}+1}$,

where, coefficients are located as follows: $c_{1}=0.5176, c_{2}=116, c_{3}=0.4, c_{4}=5, c_{5}=1$, and $c_{6}=0.0068$. The turbine characteristics can vary for different values of the pitch angle $\beta$.

The model in $d-q$ frame of the PMSG is based on (7). Besides, the electromagnetic torque $\left(T_{e m}\right)$ of the generator can be expressed as equation (11) unless $L_{q}$ is not equal to $L_{d}$,

$\left[\begin{array}{l}V_{d} \\ V_{q}\end{array}\right]=\left[\begin{array}{cc}R_{c} & -\omega L_{c} \\ \omega L_{c} & R_{c}\end{array}\right] *\left[\begin{array}{l}i_{d} \\ i_{q}\end{array}\right]+L_{c} \frac{d}{d t}\left[\begin{array}{l}i_{d} \\ i_{q}\end{array}\right]+\left[\begin{array}{c}e_{d} \\ e_{q}\end{array}\right]$,

$T_{e m}=P \varphi i_{q}$,

where, $V_{d}$ and $V_{q}$ are direct and quadratic stator voltages, $i_{d}$ and $i_{q}$ are direct and quadratic currents, $e_{d}$ and $e_{q}$ are direct and quadratic magnetic motive forces, respectively. $R_{c}$ is resistance of each stator 
phase, $\varphi$ is the permanent magnetic flux, $\square$ is the rotor electrical angular speed and $L_{c}$ is inductance of each stator phase. As to the model of PMSG in (7), taking into consideration the Clarke transformation, the PMSG model in $\alpha-\beta$ frame can be written by

$\left[\begin{array}{l}\dot{i}_{\alpha} \\ \dot{i}_{\beta}\end{array}\right]=\left[\begin{array}{cc}\frac{-R_{s}}{L_{s}} & 0 \\ 0 & \frac{-R_{s}}{L_{s}}\end{array}\right] *\left[\begin{array}{c}i_{\alpha} \\ i_{\beta}\end{array}\right]+\left[\begin{array}{cc}\frac{1}{L_{s}} & 0 \\ 0 & \frac{1}{L_{s}}\end{array}\right]\left[\begin{array}{l}V_{\alpha}-e_{\alpha} \\ V_{\beta}-e_{\beta}\end{array}\right]$,

$e_{\alpha}=-\omega \varphi \sin \theta$

$e_{\beta}=\omega \varphi \cos \theta$

where, $V_{\alpha}$ and $V_{\beta}$ are stator voltages vectors, $i_{d}$ and $i_{q}$ are stator current vectors, $e_{\alpha}$ and $e_{\beta}$ are direct and quadratic magnetic electromotive forces, respectively. $R_{c}$ is resistance of each stator phase, and $L_{c}$ is inductance of each stator phase.

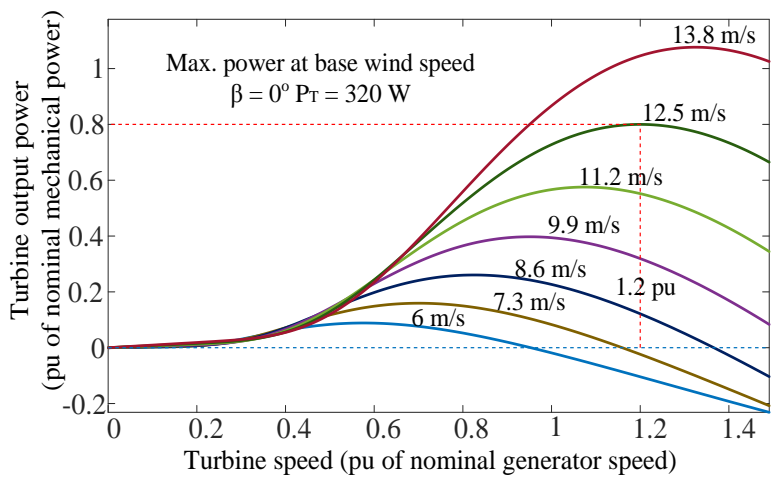

Figure 2. Turbine power characteristic versus wind speed.

\section{SYSTEM CONTROL STRATEGY}

\subsection{Conventional Control}

To control the power electronics converters which do not only use traditional multiple feedback loops but also pulse width modulation (PWM) is required. The controller is the key component in achieving a wellcontrolled and high-performance system. The DC-DC boost unidirectional converter is triggered by the duty cycle $(D)$ of the power semiconductor MOSFET thanks to the PWM signal. Equation (12) describes the output and input voltages relationship as

$V_{D C_{-} B u s}=\frac{1}{1-D} \times V_{D C-o u t}$.

A block diagram of the configuration and proportional integral (PI)-cascaded conventional control structure of the WECS is seen in Figure 3.

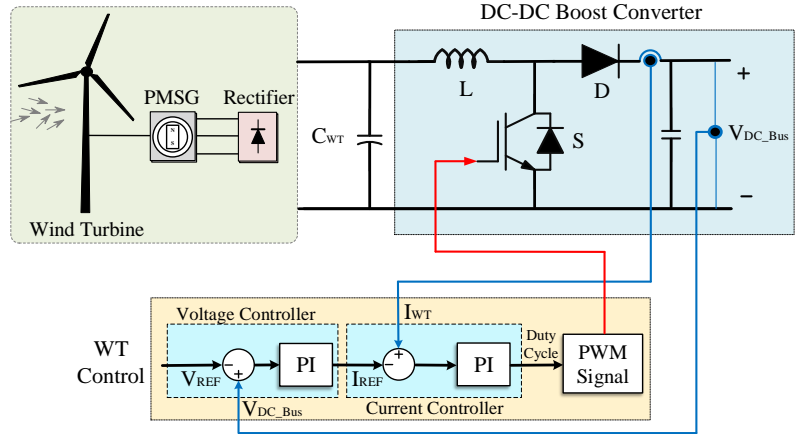

Figure 3. Configuration and control structure of WECS by PI-cascaded current and voltage controllers.

Before proceeding, it is important to mention about obtaining the necessary transfer function for any controller after simplifying and linearizing the modeled system. Where $R_{W T}=V_{W T} / I_{W T}$ is output resistance of the WECS, the transfer function between the converter input voltage $\left(V_{W T}\right)$ and the duty cycle $(D)$ can be expressed as follows with the help of the small-signal model as follows:

$$
\frac{V_{W T}(s)}{D(s)}=\frac{\frac{-V_{D C_{-} \mathrm{B} u s}}{L C_{W T}}}{s^{2}+\frac{s}{R_{W T} C_{W T}}+\frac{1}{L C_{W T}}} .
$$

\subsection{ANN-Based Control}

Essentially, AI tries to mimic the mindset in the human brain. The brains contain a lot of neurons, and these neurons are associated with biological neural networks that facilitate the behavior process. An ANN aims to mimic a sub-simulation of the biological network using electronic circuits. AI databases are applied in many fields such as software, economy, industry, and engineering [12]. Neural, statistical, and evolutionary learning are among the artificial intelligence-based multiple learning theories that ANNs are the most basic technique of neural learning [30]. The ANN was claimed by McCulloch and Pitts based on the mathematical model of a primitive cell of the human brain [31]. Roughly, a neuron is triggered by the weights of inputs that exceed the threshold limit, causing the response of activated output functions, and thus produce an appropriate output. Prediction is a sort of filtering, where past values of one or more-time series are utilized to estimate future values. Dynamic ANNs contain tapped delay lines are ready for nonlinear prediction. They are also feasible for system identification, impending failure detection, dynamic modeling of a physical model. AI can be used for simulation, analysis, visualization, and control of a variety of systems.

Another point worth mentioning is that elements of feedforward neural networks are separated layers. The signs from the input layer to the output layer are transmitted by a one-way connection. While being a 
link from one layer to the next, no link exists in the same layer. In feedforward networks, the outputs of the cells in the layers are the input of the next layer. If the layer by layer network is examined, the input layer transmits the information from the external environment to the cells in the intermediate (hidden) layer without making any changes. The output of the network is calculated by processing the input data within the hidden layers and the output layer.

A multi-layer applicator consists of one or more hidden layers and one output layer. All cells in one layer are in contact with all cells in the next layer. Feedforward is derived from the forward flow of information on behalf of networks. There is no information processing in the input layer. The number of cells in the input layer depends on the number of entries in the applied problem. Similarly, the hidden layer and the number of cells in this layer differ with the problem structure but is found by trial-and-error. The number of cells in the output layer is related to the number of outputs in the applied problem.

Feedforward networks can generally respond to problems such as classification, generalization, and recognition by applying the Delta learning rule. For the input presented to the network, the output of the network is compared with the actual result. The difference resulting from this comparison reveals the error value. The purpose of calculating backpropagation is to produce a good output by reducing the error. The error will be distributed to the weight ratings of the network every iteration.

Since nonlinear problems cannot be learned with single-layer perception, and most of the problems encountered in daily life are not linear, we have used this multi-layer feedforward neural network with Levenberg-Marquardt backpropagation in this study. This backpropagation algorithm approaches secondorder training speed regardless of computing the Hessian matrix likewise the quasi-Newton methods. When the performance function has the form of a sum of squares, the Hessian matrix and the gradient can be expressed as

$$
H=J^{T} J
$$

with

$$
g=J^{T} e
$$

where, $J$ is the Jacobian matrix that comprises of first derivatives of the network errors regarding the weights and biases, and $e$ is a vector of network errors. The Jacobian matrix can be extracted with a standard backpropagation technique which is less complicated than computing the Hessian matrix. The Levenberg-
Marquardt algorithm uses this approximation to the Hessian matrix in the following Newton-like update as

$X_{k+1}=X_{k}-\left[J^{T} J+\mu I\right]^{-1} J^{T} e$,

where, the scalar $\mu$ is zero, that is precisely Newton's method, using the approximate Hessian matrix. If $\mu$ is large, this inclines gradient descent with a small step size. Newton's method is quicker and more accurate near an error minimum, so the aim is to shift toward Newton's method as rapidly as possible.

An auxiliary network training function named "Trainlm" is generally the fastest backpropagation algorithm in the Simulink toolbox, which revises weight and bias states according to LevenbergMarquardt optimization and also is recommended as a supervised algorithm, even although it occupies more memory but less time than others. By the way, a supervised learning allows one to acquire data and then to produce a new output from previous experience i.e., correct output. It provides to improve performance criteria using this experience. Also, supervised machine learning helps us solving a variety of computational problems in the life [30].

The training process is stopped once the generalization finishes improving, as same as being in the MSE of validation process. Mentioning the operation, an ANN estimates data series of $Y(t)$, while obtaining past values up to delay $(d)$ pieces of $X(t)$ series as

$Y(t)=f \quad X \quad t-1, \ldots, X(t-d)$.

Additionally, supposing that the forms of error data series as $e_{t}=\{e\}_{t}$; where, $t=1, \ldots, n$, the neural network can be designed under four sections such as proper input selection, defining the paradigms, estimation, and lastly implementation. As stated previously, the backpropagation is a way for training the weights in a multilayer neural network [13, 32]. The generic structure of the backpropagation neural network can be expressed as follows:

$$
\begin{aligned}
& b_{h}=b_{h, j} \mid 1 \leq j \leq m, \\
& v_{t, j}=\left(\sum_{i=1}^{n}\left(w_{t, i j} X_{t, i}\right)+b_{z, j}\right) ; \quad\left\{\begin{array}{l}
i=1,2, \ldots, n \\
j=1,2, \ldots, m
\end{array},\right. \\
& Q_{t, j}=f_{\text {hidden }} v_{t, j},
\end{aligned}
$$

If an ANN consists of $n$ inputs, one hidden layer with $m$ neurons, and one output, so the output signal can be calculated as

$$
Y_{t}=f_{\text {output }}\left(\sum_{i=1}^{n} w_{t, j} Q_{t, j}+b_{k}\right),
$$


where, $X_{t, j}$ is input, $v_{t, i}, Q_{t, i}$, and $b_{h, j}$ are input, output of hidden layer (i.e, $i$ th node of hidden layer), and the bias factor for the $i^{\text {th }}$ neurons of the hidden layer respectively, $b_{y}$ is the bias factor of the neuron in the output layer, $w_{t, i j}$ and $w_{t, i}$ are connection weights, and $Y_{t}$ is output. Then the ANN generates $(m+1)^{t h}$ error points, thereby mean absolute percentage error rate, which is the average squared difference between outputs and targets, can be computed as

$$
\mathrm{MAPE}=\frac{1}{n} \sum_{t=1}^{n}\left|\frac{X(t)-Y(t)}{X(t)}\right| .100 .
$$

The structure of implemented neural network possesses one hidden layer, and its sigmoid activation function is given by

$Q_{t, j}=\frac{1}{1+e^{-v_{t, j}}}$,

also can be defined as

$Q_{t, j}=\left\{\begin{array}{ll}0 & v_{t, j}<0 \\ 1 & v_{t, j} \geq 0\end{array}\right.$.

The schematic diagram of elucidated and studied of multi-layer feedforward neural network with Levenberg-Marquardt backpropagation can be illustrated in Figure 4. Neural Net Time Series application exists in Machine Learning Toolbox of MATLAB/Simulink was used in order to implement the mentioned ANN. Implemented ANN has 3 inputs, 1 output, one hidden layer with 10 hidden neurons, and 2 delays. The node size of the hidden layer is selected based on satisfactory results. If it is selected less than average, the network cannot be trained well, otherwise, selecting more nodes causes more unnecessary complexity. On the other hand, the output depends on the historical value of the inputs, though the number of delays may result in a better performance when the system is more dynamic; however, a great deal of delays makes the training process slow. With respect to stages in the implementation phase, the data was shared to having divided into training, validation, and testing part was selected $70 \%, 15 \%$, and $15 \%$, respectively. In the training part, the network is adjusted according to the error, then is met to adapt network generalization until generalization stops training with the help of using Levenberg-Marquardt. Due to selection of simulation sample time $\left(T_{s}\right)$ as 5e-6 secs and simulation period $(\Delta T)$ as 4 secs, the number of elements can be calculated regarding $\left(1 / T_{s}\right) *(\Delta T)$. In the testing, both during and after training the network is tested for an independent measure of network performance. Besides, we embedded the input as an $800001 \times 3$ matrix, representing dynamic data 800001-time steps of 3 elements and targeted $800001 \times 1$ matrix, representing dynamic output data 800001-time steps of 1 element [13].

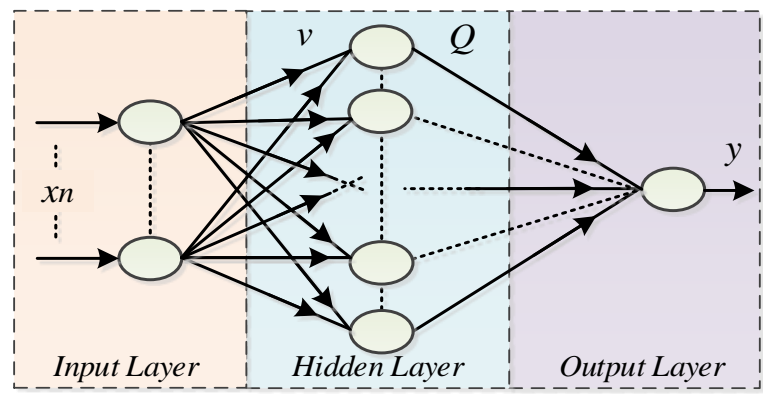

Figure 4. Schematic structure of ANN to estimate output [12].

In this paper, we have implemented a nonlinear inputoutput neural network which is simple and easy to apply. It is worth mentioning that applying ANNaided control to the WECS can be split up into two main phases regarding the offline and online part. The offline mode is met to gather the required dataset for training ANN that will be an estimator as can be depicted in Figure 5. After that phase, ANN is welltrained and prepared to estimate the desired output for the online mode. That approach alleges preparing a well-trained and tuned network via a large amount of input data (related output) in the training phase.

With the help of depth of dataset, the ANN targets to predict required inputs of the converter controller without using sensor measurements to eliminate the sensor data of the mentioned input. In the online phase, the well-tuned ANN carries out to estimate the output whose sensor needs to be eliminated in the control layer. In this context, Figure 6 depicts a general picture of the control structure that is aided by ANN.

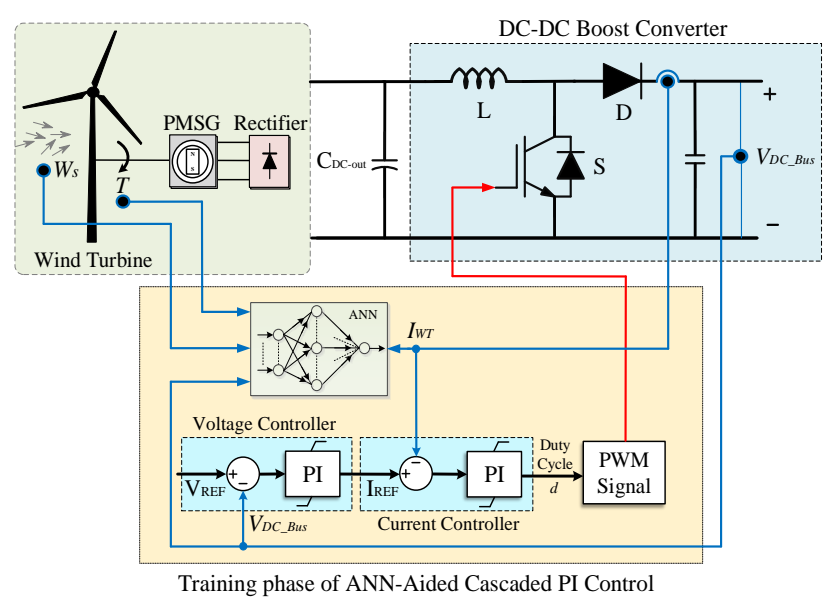

Figure 5. Control structure of WECS by ANN-Aided PI-cascaded current and voltage controllers in offline phase. 


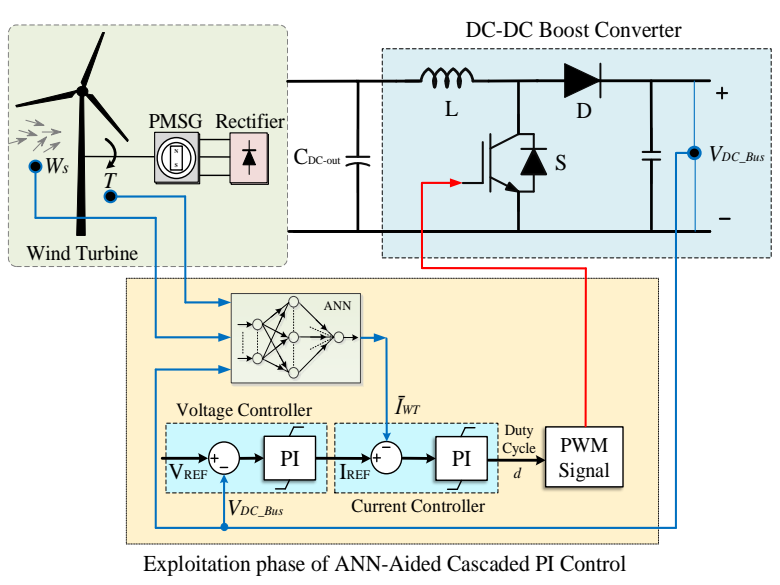

Figure 6. Control structure of WECS by ANN-Aided PI-cascaded current and voltage controllers in online phase.

\section{RESULTS}

The results of this paper has been achieved under two different variable wind speed conditions. Training of ANN yields different results because of different initial conditions and sampling. Acquiring lower values are always better, namely close to zero. In this study, best validation performance was obtained 8.1564e-11 at 1000 epochs. In Figure 7, the variable wind speed profile which considerably affects the output is given. In terms of accurate operation, regression $(R)$ values assess the correlation between outputs and targets. If $R$ value converges 1 that means a close relationship exists in Table 2, otherwise, 0 is a random relationship that needs to be edited. On the other hand, mean absolute percentage error $(M A P E)$ is the average squared difference between outputs and targets. The advantages of the proposed neural network (NN)-based methods are expressed in Table 3 based on the literature. Estimating the data with high accuracy which influences the system positively is profitable. Furthermore, it is clear that the amount of percent error is less than $10 \%$, it is considerable that is a high accuracy estimator at every moment of the simulation.

Table 2. Performance criteria of ANN under study.

\begin{tabular}{ccc}
\hline \hline \multirow{2}{*}{$\begin{array}{c}\text { CRAINING } \\
\text { PART }\end{array}$} & $\begin{array}{c}\text { CRITERIA } \\
\text { PEST } \\
\text { OF } \text { MSE }\end{array}$ & $\begin{array}{c}\text { REGRESSION- } \\
\text { R }\end{array}$ \\
\hline Training & $5.1 \mathrm{e}-08$ & 0.99 \\
Validation & $9.9 \mathrm{e}-08$ & 0.99 \\
Test & $3.4 \mathrm{e}-07$ & 0.98 \\
Overall & $7.4 \mathrm{e}-08$ & 0.99 \\
\hline \hline
\end{tabular}

Table 3. Performance criteria of ANN under study.

\begin{tabular}{|c|c|c|c|}
\hline SCHEME REF. & APPLICATION & BENEFIT & $\begin{array}{l}\text { OVERALL } \\
\text { ACCURACY }\end{array}$ \\
\hline $\begin{array}{l}\text { ANN-Based } \\
\text { MPC [19] }\end{array}$ & $\begin{array}{l}\text { Control of } \\
\text { power } \\
\text { converters }\end{array}$ & $\begin{array}{l}\text { Less } \\
\text { computational } \\
\text { effort and better } \\
\text { attenuation }\end{array}$ & $98.25 \%$ \\
\hline $\begin{array}{l}\text { FCS-MPC- } \\
\text { based NN } \\
\text { Classifier } \\
{[20]}\end{array}$ & $\begin{array}{l}\text { Voltage sag } \\
\text { classification } \\
\text { in PV system }\end{array}$ & $\begin{array}{l}\text { Enabling } \\
\text { voltage support }\end{array}$ & $98.60 \%$ \\
\hline $\begin{array}{l}\text { Long short- } \\
\text { term memory } \\
\text { NN (LSTM) } \\
{[21]}\end{array}$ & $\begin{array}{l}\text { Power } \\
\text { prediction for } \\
\text { virtual plants }\end{array}$ & $\begin{array}{l}\text { Combining the } \\
\text { concepts of } \\
\text { ANN and ML }\end{array}$ & $91 \%$ \\
\hline $\begin{array}{l}\text { Proposed } \\
\text { ANN-Based } \\
\text { PI [13] }\end{array}$ & $\begin{array}{l}\text { Sensorless } \\
\text { control of DC- } \\
\text { DC converter }\end{array}$ & $\begin{array}{l}\text { Less cost, fewer } \\
\text { needed sensors, } \\
\text { larger reliability } \\
\text { tolerance }\end{array}$ & $98.85 \%$ \\
\hline $\begin{array}{l}\text { Multilayer } \\
\text { Perception } \\
\text { ANN [22] }\end{array}$ & $\begin{array}{l}\text { Intelligent } \\
\text { Energy } \\
\text { Management }\end{array}$ & $\begin{array}{l}\text { Minimization of } \\
\text { operation costs } \\
\text { and emission }\end{array}$ & $96.01 \%$ \\
\hline
\end{tabular}

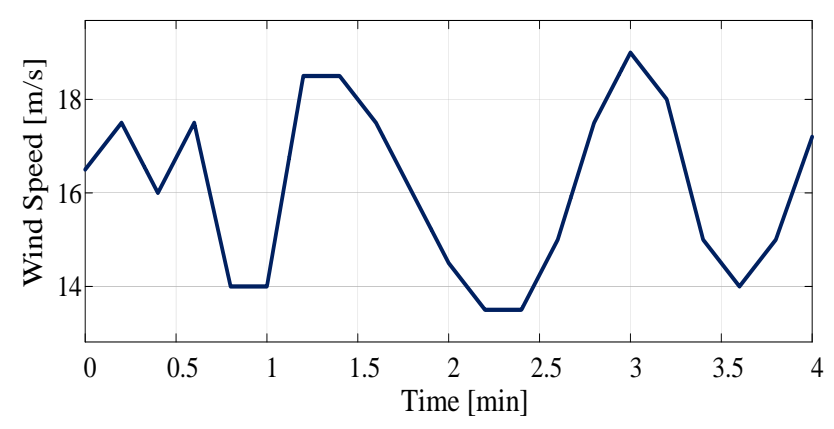

Figure 7. Variable wind speed profile-I.

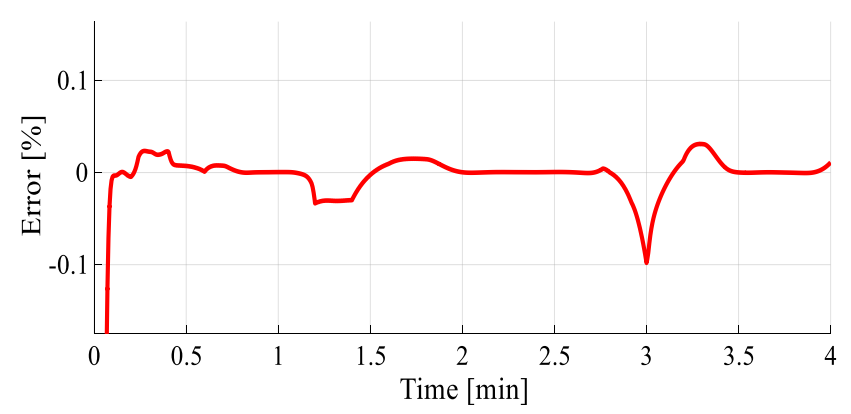

Figure 8. Percentage error values of estimated current.

The estimated value can be considered that is relatively low as seen in Figure 8. Also, Figure 9 shows one of the best validation performance of MSE results during the training process for 1000 epoch. 


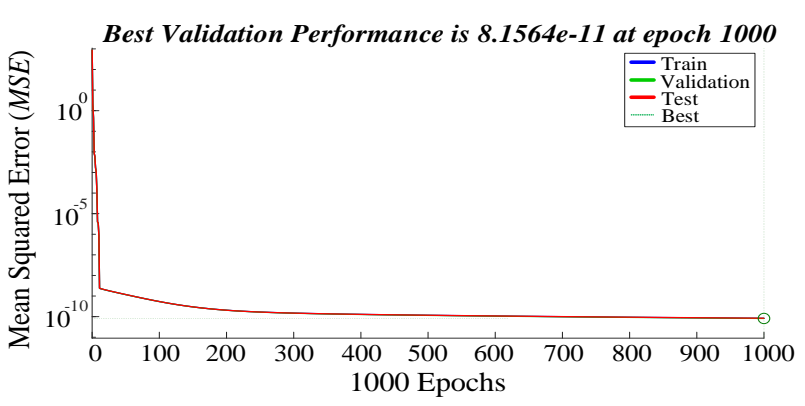

Figure 9. MSE value for output until 1000 epoch size.

Upon considering the performance criteria of the trained ANNs, the equations show the metrics in equations (25) and (26) to obtain high accuracy rates. As mentioned before, $R$ should reflect convergence to 1 , and mean squared error MSE should be near 0 as possible as much.

$$
\begin{aligned}
& R=\frac{1}{m} \sum_{t=1}^{m}\left(\frac{\left.Y_{r e f}(t)-\mu_{Y_{r e f}} * \frac{Y(t)-\mu_{Y}}{\sigma_{Y_{r e f}}}\right),}{\sigma_{Y}}\right) \\
& M S E=\sqrt{\frac{1}{m} \sum_{t=1}^{m}\left(Y_{r e f}(t)-Y(t)\right)^{2}},
\end{aligned}
$$

where, $Y_{\text {ref }}(t)$ is the desired value, $Y(t)$ is the estimated value of the proposed method, and also $\mu$ and $\sigma$ are the mean and standard deviation values, respectively. As shown in Figure 10, since the estimated value set up bears a very close resemblance to the measured data, our findings validate the usefulness of ANN-aided control for power converter with a complementary and easy way. It is clear that the estimated value can perform instead of the measured value by eliminating the relevant sensor data. For power estimation, measured and estimated powers can be shown in Figure 11.

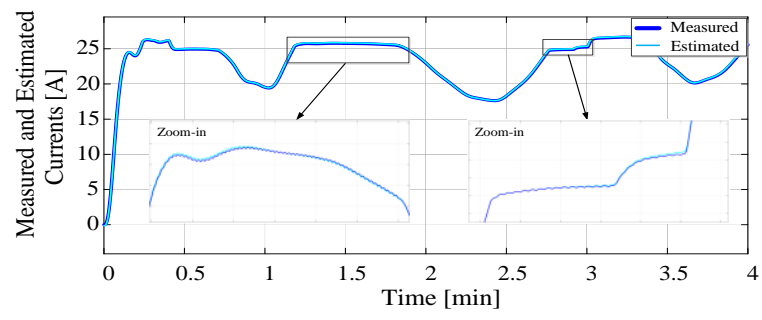

Figure 10. Measured and estimated currents.

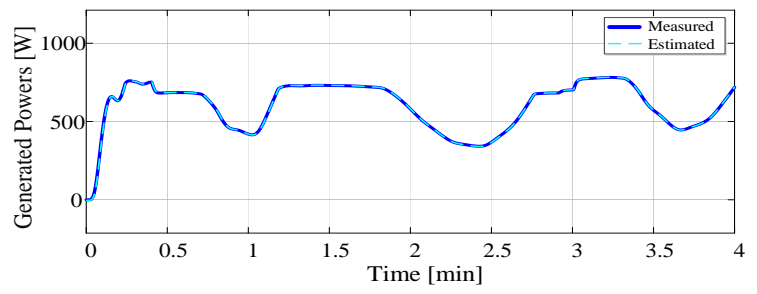

Figure 11. Measured and estimated powers regarding generated power in WECS.

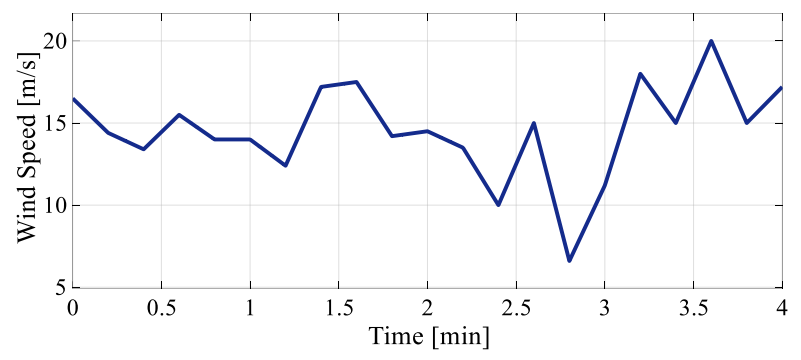

Figure 12. Variable wind speed profile-II.

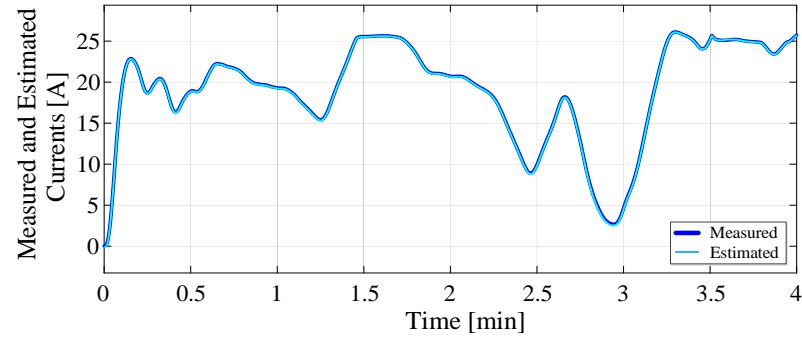

Figure 13. Measured and estimated currents.

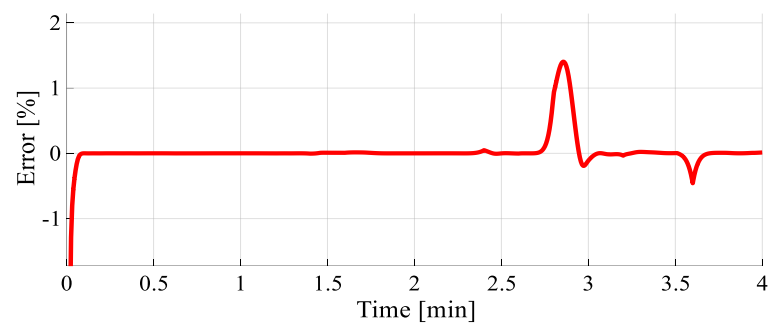

Figure 14. Percentage error values of estimated current.

For a better illustration, the second variable wind speed profile has been defined to the system to test under different conditions, as seen in Figure 12. Subsequently, measured and estimated currents in WECS is given in Figure 13. It is clear that abrupt changes in wind speed makes the system more vulnerable; however, the MAPE of this operation is still within an acceptable band in Figure 14. Once changing the percentage allocation of the target time steps for training, validation, and testing parts, the trained network achieves reaching accuracy rates as well due to having a static nonlinear relationship between inputs and output.

\section{CONCLUSION}

AI-aided namely ANN-based control of a DC-DC boost power converter in WECS was implemented in this work. The results of this work show us that the proposed method can perform like a conventional controller with a high accuracy rate. Additionally, that method enables reducing sensor requirements from the main control layer, which makes the system more reliable and cost-effective. Also, the communication challenges with sensors are diminished.

That research could possibly support the people who are interested in applied AI in energy systems. On the other hand, some better features of the system were 
obtained such as quick response and less complexity without steady-state oscillation. Depending on the gathered dataset, it is possible to estimate the instantaneous power prediction from the WECS. In terms of the findings, our results are encouraging and should be applied by real-time experimental system.

\section{REFERENCES}

[1] Kolar, J. W., Biela, J., Waffler S., Friedli, T. \& Badstuebner, U., (2011). Performance trends and limitations of power electronic systems. 2010 6th International Conference on Integrated Power Electronics Systems, Nuremberg, pp. 1-20.

[2] Melicio, R., Mendes, V. M. F. \& Catalao, J. P. S., (2010). Power converter topologies for wind energy conversion systems: Integrated modeling, control strategy and performance simulation. Renewable Energy, 35 (10), pp. 2165-2174.

[3] Hannan, M. A., et al. (2019). Power electronics contribution to renewable energy conversion addressing emission reduction: Applications, issues, and recommendations. Applied Energy, 251, p. 113404.

[4] Soliman, M. A., Hasanien, H. M., Azazi, H. Z., El-Kholy, E. E., \& Mahmoud, S. A., (2019). An Adaptive Fuzzy Logic Control Strategy for Performance Enhancement of a GridConnected PMSG-Based Wind Turbine. IEEE Transactions on Industrial Informatics, 15 (6), pp. 3163-3173.

[5] Zhang, Y., Wang, Z., Wang, H., \& Blaabjerg, F., (2020). Artificial Intelligence-Aided Thermal Model Considering Cross-Coupling Effects. IEEE Transactions on Power Electronics, 35 (10), pp. 9998-10002.

[6] Bayhan, S., Demirbaş, S., \& Abu-Rub, H., (2016). Fuzzy-PI-based sensorless frequency and voltage controller for doubly fed induction generator connected to a DC microgrid. IET Renewable Power Generation, 10 (8), pp. 1069-1077.

[7] Mesbahi, A., Aljarhizi, Y., Hassoune, A., Khafallah, M., \& Alibrahmi, E., (2020). Boost Converter implementation for Wind Generation System based on a variable speed PMSG," 2020 1st International Conference on Innovative Research in Applied Science, Engineering and Technology (IRASET), Meknes, Morocco, pp. 1-6.

[8] Deng, X. et al. (2019). Sensorless effective wind speed estimation method based on unknown input disturbance observer and extreme learning machine. Energy, 186 (115790).

[9] Wei, C., Zhang, Z., Qiao, W., \& Qu, L., (2016). An Adaptive Network-Based Reinforcement Learning Method for MPPT Control of PMSG Wind Energy Conversion
Systems. IEEE Transactions on Power Electronics, 31 (11), pp. 7837-7848.

[10] Chatri, C., \& Ouassaid, M., (2018). Sensorless Control of the PMSG in WECS Using Artificial Neural Network and Sliding Mode Observer. 2018 International Symposium on Advanced Electrical and Communication Technologies (ISAECT), Rabat, Morocco, pp. 1-6.

[11] Jday, M., \& Haggège, J., (2017). Modeling and neural networks based control of power converters associated with a wind turbine. 2017 International Conference on Green Energy Conversion Systems (GECS), Hammamet, Tunisia, pp. 1-7.

[12] Adineh, B., Habibi, M. R., Akpolat, A. N., \& Blaabjerg, F., (2021). Sensorless Voltage Estimation for Total Harmonic Distortion Calculation using Artificial Neural Networks in Microgrids. IEEE Transactions on Circuits and Systems II: Express Briefs, 68 (7), pp. 25832587.

[13] Akpolat, A. N., Dursun, E., \& Kuzucuoğlu, A. E., (2020). AI-Aided Control of a Power Converter in Wind Energy Conversion System. 2020 Innovations in Intelligent Systems and Applications Conference (ASYU), Istanbul, Turkey, pp. 1-6, doi: 10.1109/ASYU50717.2020.9259877.

[14] Samara, S., \& Natsheh, E., (2019). Intelligent Real-Time Photovoltaic Panel Monitoring System Using Artificial Neural Networks. IEEE Access, 7, pp. 50287-50299.

[15] Akpolat, A. N., Habibi, M. R., Dursun, E., Kuzucuoğlu, A. E., Yang, Y., Dragičević, T., \& Blaabjerg, F., (2021). Sensorless Control of DC Microgrid Based on Artificial Intelligence. IEEE Transactions on Energy Conversion, 36 (3), pp. 2319-2329.

[16] Egea-Àlvarez, A., Aragüés-Peñalba, M., Gomis-Bellmunt, O., Rull-Duran, J., \& SudriàAndreu, A., (2016). Sensorless control of a power converter for a cluster of small wind turbines. IET Renewable Power Generation, 10 (5), pp. 721-728.

[17] Teiar, H., Chaoui, H., \& Sicard, P., (2015). Almost parameter-free sensorless control of PMSM. IECON 2015 - 41st Annual Conference of the IEEE Industrial Electronics Society, Yokohama, pp. 004667-004671.

[18] Syskakis. T., \& Ordonez, M., (2019). MPPT for Small Wind Turbines: Zero-Oscillation Sensorless Strategy. 2019 IEEE 10th International Symposium on Power Electronics for Distributed Generation Systems (PEDG), Xi'an, China, pp. 1060-1065.

[19] Akpolat, A. N., Habibi, M. R., Baghaee, H. R. Dursun, E., Kuzucuoğlu, A. E., Yang, Y., Dragičević, T., \& Blaabjerg, F., (2021). Dynamic Stabilization of DC Microgrids using 
ANN-Based Model Predictive Control. IEEE Transactions on Energy Conversion, Early Access, doi: 10.1109/TEC.2021.3118664.

[20] Khan, M. A., Haque, A., Kurukuru, V. S. B., \& Saad, M., (2020). Advanced Control Strategy with Voltage Sag Classification for SinglePhase Grid-Connected Photovoltaic System," IEEE Trans. Emerg. Sel. Topics Ind. Electron., Early Access, doi: 10.1109/JESTIE.2020.3041704.

[21] Rosato, A., Panella, M., Araneo, R., \& Andreotti, A., (2019). A Neural Network Based Prediction System of Distributed Generation for the Management of Microgrids. IEEE Trans. Ind. Appl., 55 (6), pp. 7092-7102.

[22] Chaouachi, A., Kamel, R. M., Andoulsi, R., \& Nagasaka, K., (2013). Multiobjective Intelligent Energy Management for a Microgrid. IEEE Trans. Ind. Electron., 60 (4), pp. 1688-1699.

[23] Peyghami, S., Dragicevic, T., \& F. Blaabjerg., (2021). Intelligent long-term performance analysis in power electronics systems. Sci. Rep., 11 (1), pp. 1-18.

[24] Habibi, M. R., Baghaee, H. R., Blaabjerg, F., \& Dragičević, T., (2021). Secure Control of DC Microgrids for Instant Detection and Mitigation of Cyber-Attacks Based on Artificial Intelligence. Early Access, IEEE Systems Journal, doi: 10.1109/JSYST.2021.3119355.

[25] Farooq, Z., Zaman, T. M., Khan, A., Nasimullah, Muyeen, S. M., \& Ibeas A., (2019). Artificial Neural Network Based Adaptive Control of Single Phase Dual Active Bridge With Finite Time Disturbance
Compensation. IEEE Access, 7, pp. 112229112239.

[26] Li, X., Zhang, X., Lin, F., \& Blaabjerg, F., (2021). Artificial-intelligence based design (AI-D) for circuit parameters of power converters. IEEE Trans. Ind. Electron., Early Access, doi: 10.1109/TIE.2021.3088377.

[27] Wang, T. He, X., \& Deng, T., (2019). Neural networks for power management optimal strategy in hybrid microgrid. Neural Comput \& Applic 31, pp. 2635-2647.

[28] Onar, O. C., \& Khaligh, A., (2015). Alternative Energy in Power Electronics. Chapter 2 Energy Sources, 1st ed., UK: ButterworthHeinemann, Elsevier, 2015, pp. 81-154.

[29] Heier, S., (2014). Wind Energy Conversion System. Grid Integration of Wind Energy: Onshore and Offshore Conversion Systems, 3rd ed., Germany: John Wiley \& Sons, pp. 31-117.

[30] Akpolat, A.N., (2021). Management And Control of Distributed Energy Generation Systems via Artificial Intelligence Techniques. Doktora Tezi, Marmara Üniversitesi, Türkiye, pp. 37-38.

[31] Piccinini, G., (2004). The first computational theory of mind and brain: A close look at McCulloch and Pitts's Logical Calculus of Ideas Immanent in Nervous Activity. Synthese, 141, pp. 75-215.

[32] Rathnayaka, R. M. K. T., \& Seneviratna, D. M. K. N., (2019). A Novel Hybrid Back Propagation Neural Network Approach for Time Series Forecasting Under the Volatility. Communications in Computer and Information Science, Singapore. 